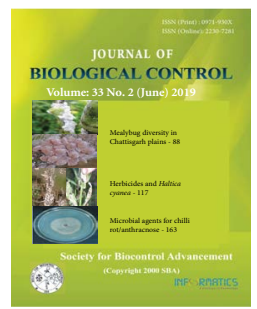

Research Article

\title{
Bio-efficacy of different biological control agents for the management of chilli fruit rot/anthracnose disease
}

\author{
B. L. RAGHUNANDAN*, MAYANK V. PATEL, NEHA M. PATEL and D. M. MEHTA \\ AICRP on Biological Control of Crop Pests, Anand Agricultural University, Anand - 388 110, Gujarat, India \\ *Corresponding authorE-mail: raghumic2@gmail.com
}

\begin{abstract}
Chilli (Capsicum annum L.) an important economic crop worldwide is severely infected by fruit rot disease which may cause yield losses of up to $100 \%$. Although different chemical fungicides are being recommended and used for the management of the disease, biocontrol-based strategy attracts considerable attention and offers great potential of novel biocontrol agents. Further, biological control methods for chilli fruit rot/anthracnose disease have not received much attention. Therefore, an investigation was carried out to assess the efficacy of different biological control agents against chilli fruit rot/anthracnose disease. Antagonistic yeast isolates Pichia guillermondii (Y-12), Hanseniaspora uvarum (Y-73) and Trichoderma asperellum (Th-3), Pseudomonas fluorescens (Pf-1) were tested through seed treatment, seedling dip and foliar spray at concentration of $2 \times 10^{8} \mathrm{cfu} / \mathrm{g}$. The pathogens viz., Colletotrichum capsici, Alternaria alternata and Periconia byssoides were found associated with fruit rot during the study. Lowest mean disease intensity (MDI), highest disease control (DC) over untreated control was recorded in the treatment P. guillermondii (Y-12) $(5.39 \% \mathrm{MDI}, 64.72 \%$ DC) and this was found at par with the treatment $P$. fluorescens (Pf-1) $(5.92 \%$ MDI, 65.52\% DC). However, T. asperellum (Th-3) showed satisfactory results. The present study highlights the efficacy of antagonistic yeast species against chilli fruit rot pathogens and these findings serve as base for further exploration and exploitation of yeast species for eco-friendly management of crop diseases.
\end{abstract}

KEY WORDS: Biological control, chilli fruit rot, Colletotrichum, Pichia guillermondii

(Article chronicle: Received: 26-12-2018; Revised: 14-02-2019; Accepted: 25-03-2019)

\section{INTRODUCTION}

Chilli is an important economic crop worldwide and decisive component of the cuisines of tropical and subtropical countries (Saxena et al., 2016). In India during 2016-17, area under chilli cultivation was recorded as 8.31 million ha with total production of 18.72 million tons (Anon, 2018). Chilli is severely infected by fruit rot/anthracnose disease which may cause yield losses of up to $100 \%$ under congenial environment conditions (Pakdeevaraporn et al., 2005; Poonpolgul and Kumphai, 2007). Colletotrichum spp. and Alternaria spp. are seed borne, highly destructive pathogens worldwide causing economically important disease in a wide range of hosts including cereals, legumes, vegetables, perennial crops and tree fruits. Typical fruit rot/anthracnose symptoms on chilli fruit include sunken necrotic tissues, with concentric rings of acervuli. Fruits showing blemishes have reduced marketability and this has been reported to be a major constraint in chilli production in tropical and subtropical countries (Ramachandran and Rathnamma, 2006).

Although different chemical fungicides are being recommended and used to combat the disease, there is a pressing need to explore biocontrol-based strategy for the management of crop diseases in the present arena of organic agriculture. So far, biological control methods for chilli fruit rot/anthracnose disease have not received much attention. The potential for biological control of Colletotrichum species had been suggested as early as in 1970s by Lenné and Parbery (1976). It is also believed that Trichoderma species are able to effectively compete for surface area, thereby reducing pathogen infection success (Maymon et al., 2004). Other biological control agents that have been tested for efficacy against Colletotrichum species include Pseudomonas fluorescens, Bacillus subtilis and antagonistic yeast species Pichia guillermondii, Candida 
Bio-efficacy of different biological control agents for the management of chilli fruit rot/anthracnose disease

oleophila etc. But, these findings are primarily based on in vitro studies. Assessment of field efficacy of these bioagents is most inevitable to establish biocontrol strategies for the management of the disease. With this view field experiments were conducted in the year 2016-17 and 2017-18 to evaluate the efficacy of different biocontrol agents against chilli fruit rot/anthracnose disease under All India Coordinated Research Project on Biological Control of Crop Pests (AICRP-BC).

\section{MATERIALS AND METHODS}

To assess the efficacy of different biological control agents on fruit rot/anthracnose disease in chilli, field experiments were conducted at Agronomy experimental farm, B.A. College of Agriculture, Anand Agricultural University, Anand (Gujarat) during Kharif 2016-17 and Kharif 2017-18. Chilli variety GCV-131 variety was raised in nursery, transplanted at spacing of $60 \times 60 \mathrm{~cm}$ and grown by adapting standard agronomic practices except plant protection. There were six different treatments comprising of two different antagonistic yeast species, viz., T1: Pichia guilliermondii (Y-12; NCBI HQ448930) 1\% AS, T2: Hanseniaspora uvarum (Y-73; NCBI JQ247580) 1\% AS, T3: Trichoderma asperellum (Th-3; NCBI JQ013144) 1\% WP, T4: Pseudomonas fluorescens (Pf-1 from institute culture collection) 1\% AS, T5: fungicide carbendazim 50\% WP, and T6: untreated control. Pure cultures and formulations of biocontrol agents were obtained from ICAR-National Bureau of Agriculturally Important Insects, Bengaluru, India. All the treatments were replicated four times in Randomized Block Design (RBD).

\section{Method of application}

\section{Seed treatment}

The seeds were treated with formulations before sowing in nursery. $10 \mathrm{ml}$ or 10 grams of concentrated formulation was mixed with $100 \mathrm{ml}$ of water and used to treat $1 \mathrm{~kg}$ seeds. The seeds were soaked in formulation for 5 minutes with constant shaking and then the treated seeds were shade dried for 30 minutes and used for sowing.

\section{Seedling dip}

Chilli seedlings grown in nursery beds were treated with antagonist formulation before transplantation. $20 \mathrm{ml}$ or $20 \mathrm{gm}$ of formulation was mixed with 1 litre water to get antagonist suspension for seedlings treatment. Seedlings were uprooted carefully from nursery beds and roots were dipped in antagonist suspension for 5 minutes and transplanted in main field.

\section{Foliar spray}

Foliar spray of antagonist formulation was given at the rate of $10 \mathrm{~g}$ or $10 \mathrm{ml}$ per litre of water using a high volume sprayer with a spray fluid volume of $500 \mathrm{~L} / \mathrm{ha}$. First spray was given at initiation of fruit ripening and later three sprays were given at fortnightly intervals.

\section{Observations recorded}

\section{Disease intensity}

Total numbers of healthy and diseased fruits in each labelled plant (Five plants/treatment) was counted and percent fruit rot incidence was calculated using the following formula (Ferdousi Begum et al., 2010).

$$
\text { Fruit rot intensity }(\%)=\frac{\text { Number of infected fruits }}{\text { Total number of healthy fruits }} \times 100
$$

\section{Yield (q/ha)}

Weight of healthy and marketable fruits from each treatment was recorded and total yield obtained was converted to quintal/ha basis.

\section{Isolation and identification of pathogen during field experiment}

Small segments of diseased tissue from the infected fruit samples were cut by sterile razor and surface sterilized in $0.1 \%$ sodium hypochlorite $(\mathrm{NaOCl})$ for one minute. Surface sterilized tissue was rinsed in double distilled water to remove the traces of sodium hypochlorite. Tissues were dried on sterile filter paper and placed in Petri plates containing Potato Dextrose Agar (PDA) medium amended with $100 \mu \mathrm{g} /$ $\mathrm{ml}$ of streptomycin sulphate. The plates were incubated at $26 \pm 1{ }^{\circ} \mathrm{C}$ in BOD incubator and observed for fungal growth. Single spore isolation method was followed to purify the fungal pathogens (Tutte, 1969). Colony morphology and microscopic features of all the fungal pathogens obtained were studied on PDA as described by Simmons (2007) (Figure 3). After pathogen identification pathogenicity tests were performed to confirm Koch's postulates.

\section{Molecular characterization}

For molecular characterization pathogen cultures were cultured on potato dextrose broth for 12 days at room temperature. The mycelium was harvested, dried and powdered by using liquid nitrogen. Genomic DNA was extracted by cetyltrimethylammonium bromide (CTAB) method as described by Chakraborty et al., (2010). PCR amplification of internal transcribed spacer (ITS) region was performed by following standard protocol (Hebert et al., 2003). Primers used for amplification were: forward primer (ITS1 5'-TCCGTAGGTGAACCTGCGG-3') and reverse primer (ITS4 5'- TCCTCCGCTTATTGATATGC-3'). The amplified products were sequenced by capillary sequencer 
ABI-3130. Gene sequence was checked for homology by using NCBI-BLAST database.

\section{Statistical analysis}

Data on disease intensity and yield was recorded and statistically analysed with the help of computer package program SPSS (SPSS Inc, Chicago, IL, USA).

\section{RESULTS AND DISCUSSION}

In the year 2016-17, treatment of antagonistic yeast species Pichia guilliermondii (Y-12) - seed treatment, seedling dip and foliar spray $\left(2 \times 10^{8} \mathrm{cfu} / \mathrm{g}\right)$ found best with low disease intensity $(6.23 \%)$ and highest yield $(83.27 \mathrm{q} / \mathrm{ha})$ (Table 1). This treatment was found at par with the treatment Pseudomonas fluorescens (Pf-1) - seed treatment, seedling dip and foliar spray $\left(2 \times 10^{8} \mathrm{cfu} / \mathrm{g}\right)$ with disease intensity of $6.58 \%$ and fruit yield $79.99 \mathrm{q} / \mathrm{ha}$. Another yeast species Hanseniaspora uvarum (Y-73) also showed moderate disease control $(60.20 \%)$ compared to other biocontrol agents evaluated (Fig.1). The lowest disease control (50.41\%) was recorded in the treatment Trichoderma asperellum (Th-3) with disease intensity of $8.51 \%$. In the year $2017-18$, seed treatment, seedling dip and foliar spray $\left(2 \times 10^{8} \mathrm{cfu} / \mathrm{g}\right)$ of $P$. guilliermondii (Y-12) found best with low disease intensity $(4.60 \%)$ and highest yield (85.23 q/ha) followed by seed treatment, seedling dip and foliar spray $\left(2 \times 10^{8} \mathrm{cfu} / \mathrm{g}\right)$ of $P$. fluorescens (Pf-1) with disease intensity of $5.30 \%$ and fruit yield $81.99 \mathrm{q} /$ ha (Table 1). T. asperellum (Th-3) showed moderate disease control $(56.87 \%)$ compared to other agents. Lowest disease control $(55.53 \%)$ was recorded in the treatment $H$. uvarum (Y-73) with disease intensity of $7.64 \%$. None of the biocontrol treatments found superior than fungicide treatment (Carbendazim 0.05\%) where lowest disease intensity (3.23\%) and highest yield (92.45 q/ ha) was recorded. Pooled data of disease intensity over two consecutive years reveals the consistent performance and field efficacy of promising biocontrol agents in reducing the disease intensity (Fig. 1). Treatment P. guilliermondii (Y12) found best which was followed by P. fluorescens (Pf-1). Similar trend was recorded in healthy fruit yield among biocontrol treatments. The treatment P. guilliermondii (Y-12) recorded the highest yield $(84.25 \mathrm{q} / \mathrm{ha})$ and it was on par with the treatment $P$. fluorescens (Pf-1) $(80.89 \mathrm{q} / \mathrm{ha}$ ) and which was followed by the treatment T. asperellum (Th-3) (74.35 q/ha) (Table 1).

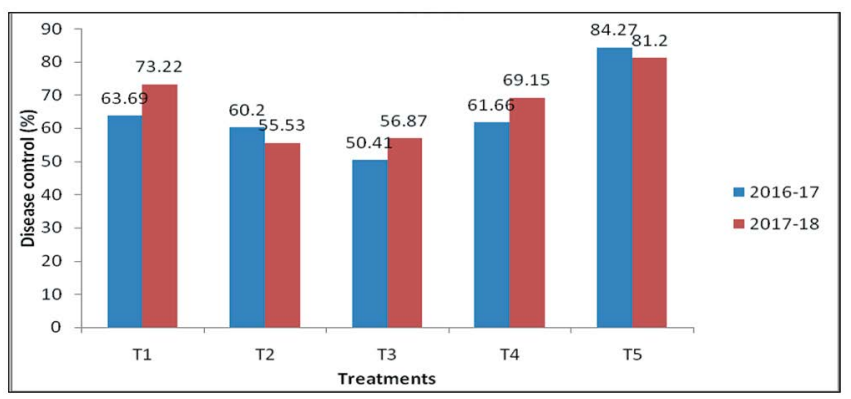

Fig. 1. Comparative efficacies of different biological control agents against chilli fruit rot /anthracnose disease

Table 1. Effect of different bio-control agents on fruit rot/anthracnose disease and yield of chilli

\begin{tabular}{|c|c|c|c|c|c|c|}
\hline \multirow[t]{2}{*}{ Treatments } & \multicolumn{3}{|c|}{ Disease intensity (\%) } & \multicolumn{3}{|c|}{ Healthy fruit yield (q/ha) } \\
\hline & 2016-17 & $2017-18$ & Pooled & $2016-17$ & $2017-18$ & Pooled \\
\hline Pichia guilliermondii (Y-12) & $\begin{array}{l}14.45 b \\
(6.23)\end{array}$ & $\begin{array}{l}12.39 \mathrm{~b} \\
(4.60)\end{array}$ & $\begin{array}{c}13.42 \mathrm{~b} \\
(5.39)\end{array}$ & $83.27 \mathrm{~b}$ & $85.23 b$ & $84.25 b$ \\
\hline Hanseniaspora uvarum (Y-73) & $\begin{array}{l}15.15 b \\
(6.83)\end{array}$ & $\begin{array}{l}16.05 \mathrm{c} \\
(7.64)\end{array}$ & $\begin{array}{c}15.60 \mathrm{bc} \\
(7.23)\end{array}$ & $75.60 \mathrm{c}$ & $71.73 \mathrm{~d}$ & $73.66 \mathrm{c}$ \\
\hline Trichoderma asperellum (Th-3) & $\begin{array}{l}16.96 \mathrm{c} \\
(8.51)\end{array}$ & $\begin{array}{l}15.80 \mathrm{c} \\
(7.41)\end{array}$ & $\begin{array}{l}16.38 \mathrm{c} \\
(7.95)\end{array}$ & $70.85 \mathrm{~d}$ & $77.84 \mathrm{~cd}$ & $74.35 \mathrm{c}$ \\
\hline Pseudomonas fluorescens (Pf-1) & $\begin{array}{l}14.86 \mathrm{~b} \\
(6.58)\end{array}$ & $\begin{array}{l}13.31 \mathrm{~b} \\
(5.30)\end{array}$ & $\begin{array}{l}14.08 b c \\
(5.92)\end{array}$ & $79.79 b$ & $81.99 b c$ & $80.89 b$ \\
\hline $\begin{array}{l}\text { Recommended fungicide } \\
\text { (Carbendazim } 0.05 \% \text { ) }\end{array}$ & $\begin{array}{l}9.45 \mathrm{a} \\
(2.70)\end{array}$ & $\begin{array}{l}10.35 \mathrm{a} \\
(3.23)\end{array}$ & $\begin{array}{l}9.90 \mathrm{a} \\
(2.96)\end{array}$ & $90.52 \mathrm{a}$ & $92.45 \mathrm{a}$ & $91.48 \mathrm{a}$ \\
\hline Untreated control & $\begin{array}{l}24.47 d \\
(17.16)\end{array}$ & $\begin{array}{l}24.49 d \\
(17.18)\end{array}$ & $\begin{array}{l}24.48 \mathrm{~d} \\
(17.17)\end{array}$ & $44.13 \mathrm{e}$ & $42.96 \mathrm{e}$ & $43.55 \mathrm{~d}$ \\
\hline $\mathrm{SEM} \pm \mathrm{T}$ (Treatment) & 0.35 & 0.39 & 0.64 & 1.26 & 2.28 & 1.39 \\
\hline C. D. @ 5\% T & 1.00 & 1.11 & 2.32 & 3.80 & 6.88 & 3.99 \\
\hline C. V. $(\%)$ & 8.90 & 10.21 & 9.56 & 3.40 & 6.10 & 4.93 \\
\hline
\end{tabular}

Figures in parentheses are retransformed values; those outside are arc sine transformed values 
The results of the field experiment were found encouraging for the eco-friendly management of the disease. The biocontrol potential could be attributed to competitive colonization, antibiosis and induction of systemic resistance in crop plants by efficient biocontrol agents and antagonistic yeast could be a promising component of integrated management of chilli fruit rot/anthracnose disease.

Similar findings were also documented form various researchers across the world (Vasanthakumari and Shivanna, 2013; Ashwini and Srividya, 2014; Jaihan et al., 2016). Trichoderma species have been reported for the efficient management of chilli fruit rot caused by Colletotrichum species (Boonnartkwang et al., 2007; Ferdousi Begum, 2010). In addition, antagonistic bacterial strains were documented for the effective control of fruit rot disease in chilli (Intanoo and Chamswarng, 2007). Other microbial agents viz., $B$. subtlis and Saccharomyces cerevisiae were reported to be antagonistic to fruit rot pathogens of chilli (Jeyalakshmi and Seetharaman, 1998) and it has been elucidated that secretion of extracellular enzymes that degrade the pathogenic mycelia and restrict the further colonization in host tissues (Singh et al., 2012). Recently, antagonistic yeast species have received significant attention for the management of post harvest diseases and fruit rot diseases (Rosa Magri et al., 2011). Antagonistic yeast $P$. guillermondii strain R13 was found effective in reducing the disease incidence on C. capsici infected fruits to as low as $6.5 \%$ (Chanchaichaovivat et al., 2007).

During isolation of fruit rot pathogen from infected fruits, three different pathogens were found associated with chilli fruit rot in the experimental plot. Three different pathogens were identified as Colletotrichum capsici (AAUBC-Cc1), Alternaria alternata (AAUBC-Aa1) and Periconia byssoides (AAUBC-Pb1) based on morphological features and microscopic observations. C. capsici isolate produced cottony greyish-white to dark grey mycelium with large number of black acervuli at initial stages which later turned to light brown color. Conidia were falcate, fusiform with acute apices and narrow truncated, one celled, hyaline and uninucleate. Subhani (2015) identified the disease symptoms in chilli, isolated and identified the pathogen $C$. capsici based on sporulating acervuli, conidia and setae. Similarly, the pathogen A. alternata produced gray brown to olivaceous coloured, branched septate mycelium. The conidia were ovate or obpyriform to ellipsoidal in chain, brown to golden brown with 3-8 transverse and 1-2 longitudinal septations. Nagrale et al. (2013) reported the morphological features of $A$. alternata and highlighted that the fungus initially produces hyaline mycelium that later turned to grey-brownish, irregularly branched, septate and multicelled mycelium. P. byssoides reported as pathogen rarely associated with fruit rot of chilli was isolated from the infected fruits and identified (Basak et al., 1994). The fruits artificially inoculated with conidial suspension of three different fruit rot pathogens (individual inoculation) showed typical symptoms of fruit rot/anthracnose. The pathogens were re-isolated from the symptom expressed fruits and morphological features were confirmed with original isolates (Fig. 2).

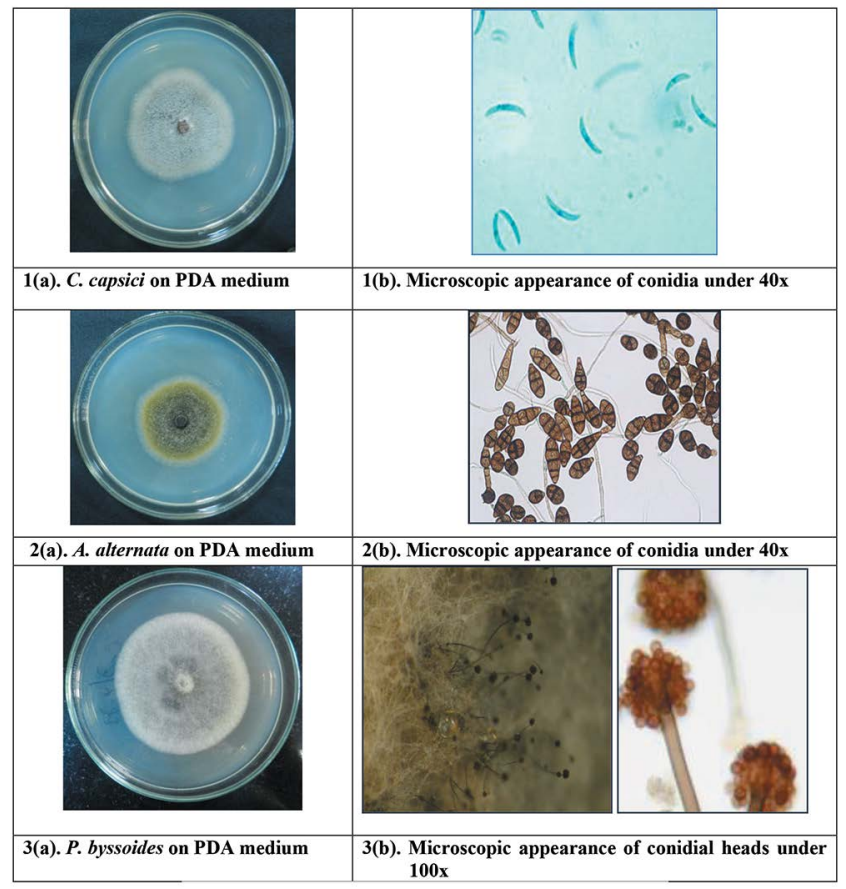

Fig. 2. Pathogens associated with fruit rot disease of chilli.

Further, molecular characterization of pathogenic isolates (3) using Internal Transcribed Spacer (ITS) gene confirmed the identification of pathogens done through morphologically. Amplicon of $\sim 570 \mathrm{bp}$ was obtained with the use of universal primers ITS1 and ITS4 (Fig. 3). Gene sequences were deposited in the NCBI database and were assigned with accession numbers (C. capsici (AAUBC-Cc1) - MH010314, A. alternata (AAUBC-Aa1) - MH010315 and P. byssoides (AAUBC-Pb1) - MH010316). Similar findings were reported by (Torres-Calzada et al., 2011; Guo-yin et al., 2013).

By analyzing the results of reduction in fruit rot disease and fruit yield of the crop under the influence of different biocontrol agents, it is concluded that antagonistic yeast species P. guilliermondii (Y-12) and bacterial biocontrol agent $P$. fluorescens (Pf-1) are promising antagonists for the biological control of chilli fruit rot/anthracnose disease. 


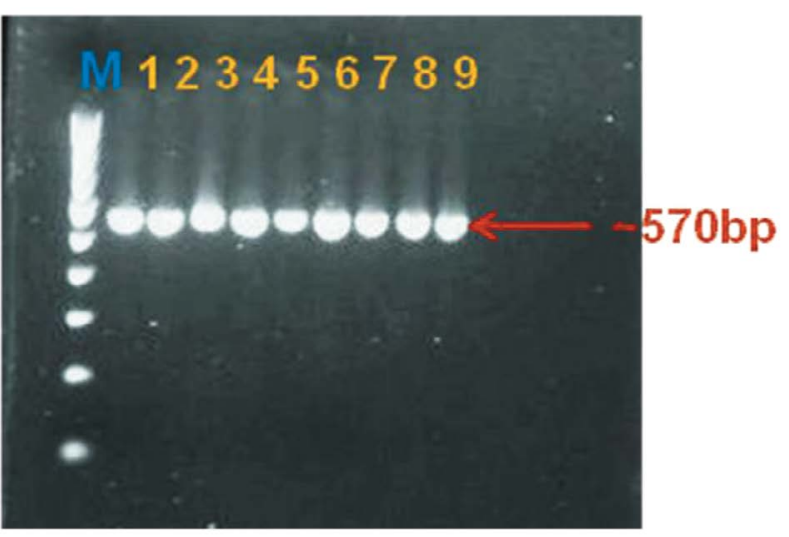

Fig. 3. Molecular characterization of chilli fruit rot pathogenic isolates through ITS gene ( $\sim 570 \mathrm{bp})$ amplification (M- 1 kb molecular ladder; Lane 1,2,3 - Isolate AAUBC-Cc1; Lane 4,5,6 - Isolate AAUBC-Aa1; Lane 7,8,9- Isolate AAUBC-Pb1).

\section{ACKNOWLEDGEMENT}

Authors sincerely acknowledge Director of Research and Dean PG studies, Anand Agricultural University, Anand, Gujarat, for his constant support and encouragement to conduct research in the field of biological control and are thankful to the Director, ICAR-National Bureau of Agriculturally Important Insects, Bengaluru, India, for the supply of microbial formulations for field experiment and financial grants under All India Co-ordinated Research Project on Biological Control of Crop Pests (AICRP-BC) scheme.

\section{REFERENCES}

Anonymous. 2018. Chilli Outlook, February, Agricultural Market Intelligence Centre, PJTSAU. pp. 1-5.

Ashwini N, Srividya S. 2014. Potentiality of Bacillus subtilis as biocontrol agent for management of anthracnose disease of chilli caused by Colletotrichum gloeosporioides OGC1. 3Biotech 4: 127-136.

Basak AB, Fakir GA, Mridha MAU. 1994. Studies on the prevalence of six major fruit rot diseases of chilli at different stages of fruit development in Chittagong district. Chittagong Uni Stud Sci. 18: 125-128.

Boonratkwang C, Chamswarng C, Intanoo W, Juntharasri V. 2007. Effect of secondary metabolites from Trichoderma harzianum strain $\mathrm{pm} 9$ on growth inhibition of Colletotrichum gloeosporioides and chilli anthracnose control, pp. 232-336. Proceeding of the 8th National Plant Protection Conference, Phisanulok:Naresuan University, Chang Wat Phitsanulok 65000, Thailand.
Chakraborty BN, Chakraborty U, Saha A, Dey PL, Sunar K. 2010. Molecular characterization of Trichoderma viride and Trichoderma harzianum isolated from soils of North Bengal based on rDNA markers and analysis of their PCR-RAPD profiles. Global J Biotech Biochem. 5(1): 55-61.

Chanchaichaovivat A, Ruenwongsa P, Panijpan B. 2007. Screening and identification of yeast strains from fruit and vegetables: potential for biological control of postharvest chilli anthracnose (Colletotrichum capsici). Biol Control 42: 326-335. https://doi.org/10.1016/j.biocontrol.2007.05.016

Ferdousi Begum M, Rahman MA, Firoz Alam M. 2010. Biological control of Alternaria fruit rot of chilli by Trichoderma species under field condition. Mycobiology 38: 113-117. https://doi.org/10.4489/MYCO.2010.38.2.113 PMid:23956637 PMCid: PMC3741560

Guo-yin T, Zgi-Ling Y, Zhi-lin Y, Shou-an S. 2013. Morphological, molecular and pathologenic characterization of Alternaria longipes, the fungal pathogen causing leaf spot on Atractylodes macrocephala. African J Microbiol Res. 7: 2589-2595. https://doi.org/10.5897/AJMR12.2091

Hebert PDN, Cywinska A, Ball SL, DeWaard JR. 2003. Biological identifications through DNA barcodes. Proc Royal Soc London Series B-Biol Sci. 270:313-321.https:// doi.org/10.1098/rspb.2002.2218 PMid:12614582 PMCid:PMC1691236

Intanoo W, Chamswarng C. 2007. Effect of antagonistic bacterial formulations for control of anthracnose on chilli Fruits, pp. 309-322. Proceeding of the 8th National Plant Protection Conference, Phisanulok:Naresuan University, Chang Wat Phitsanulok 65000, Thailand.

Jaihan P, Sangdee K, Sangdee A. 2016. Selection of entomopathogenic fungus for biological control of chili anthracnose disease caused by Colletotrichum spp. European $J$ Plant Pathol. 146: 551-564. https://doi.org/10.1007/s10658-016-0941-7

Jeyalakshmi C, Seetharaman K. 1998. Biological controls of fruit rot and die-back of chilli with plant products and antagonistic microorganisms. Plant Dis Res. 13: 46-48.

Lenné JM, Parbery DG. 1976. Phyllosphere antagonists and appressoria formation in Colletotrichum gloeosporioides. Tranc Brit Mycol Soc. 66: 334-336. https://doi.org/10.1016/S0007-1536(76)80065-4 
Maymon M, Barbul DMO, Zveibil A, Elad Y, Freeman S. 2004. Identification of Trichoderma biocontrol isolates to clades according to ap-PCR and ITS sequence analyses. Phytoparasi. 32: 370-375. https://doi. org/10.1007/BF02979848

Nagrale DT, Gaikwad AP, Sharma L. 2013. Morphological and cultural characterization of Alternaria alternata (Fr.) Keissler blight of gerbera (Gerbera jamesonii H. Bolus ex J.D. Hook). J Appl Nat Sci. 5: 171-178. https://doi.org/10.31018/jans.v5i1.302

Pakdeevaraporn P, Wasee S, Taylor PWJ, Mongkolporn O. 2005. Inheritance of resistance to anthracnose caused by Colletotrichum capsici in capsicum. $P l$ Breed. 124: 206-208. https://doi.org/10.1111/j.14390523.2004.01065.x

Poonpolgul S, Kumphai S. 2007. Chilli pepper anthracnose in Thailand: Country report. pp.23. In: Oh, DG and K. T. Kim, KT (Eds.). Abstracts of the First International Symposium on Chilli Anthracnose. National Horticultural Research Institute: Rural Development of Administration, Republic of Korea.

Ramachandran N, Rathnamma K. 2006. Colletotrichum acutatum - a new addition to the species of chilli anthracnose pathogen in India. Paper Presented at the Annual Meeting and Symposium of Indian Phytopathological Society, Central Plantation Crops Research Institute, Kasaragod, Kerala, India.

Rosa Magri MM, Tauk-Tornisielo SM, Ceccato Antonini SR. 2011. Bioprospection of yeasts as biocontrol agents against phytopathogenic molds. Braz Arch
Biol Technol. 54: 1-5.https://doi.org/10.1590/S151689132011000100001

Saxena A, Raghuwanshi R, Gupta VK, Singh HB. 2016. Chilli anthracnose: the epidemiology and management. Front Microbiol. 7: 1527. https://doi.org/10.3389/ fmicb.2016.01527 PMid:27746765 PMCid:PMC5044472

Simmons EG. 2007. Alternaria. An Identification Manual. CBS Biodiversity Series No. 6. CBS Fungal Biodiversity Centre, Utrecht, the Netherlands, 775 pp.

Singh HB, Singh BN, Singh SP, Sarma BK. 2012. Exploring different avenues of Trichoderma as a potent biofungicidal and plant growth promoting candidate an over view. Rev Plant Pathol. 5: 315-426.

Subhani MN. 2015. Isolation and efficacy of fungicides and homeo-fungicides against anthracnose of chilies caused by Colletotrichum capsici. Pakistan J Nutri. 14: 325-329. https://doi.org/10.3923/pjn.2015.325.329

Torres-Calzada C, Tapia-Tussell R, Quijano-Ramayo A, Martin-Mex R, Perez-Brito D. 2011. A species-specific polymerase chain reaction assay for rapid and sensitive detection of Colletotrichum capsici. Mol Biotechnol. 49: 48-55. https://doi.org/10.1007/s12033-011-9377-7 PMid:21253896

Tutte J. 1969. Plant pathological methods fungi and bacteria. Burgess Publishing Company, USA, 229 pp.

Vasanthakumari MM, Shivanna MB. 2013. Biological control of anthracnose of chilli with rhizosphere and rhizoplane fungal isolates from grasses. Arch Phyto Pathol. 46: 1641-1666. https://doi.org/10.1080/03235408.2013.771901 